\title{
Bacterial Streak and Bulb Rot of Sweet Onion: II. Epiphytic Survival of Pseudomonas viridiflava in Association with Multiple Weed Hosts
}

\author{
R. Gitaitis, Department of Plant Pathology, University of Georgia, Tifton 31793; G. MacDonald, Cooperative \\ Extension Service, Rural Development Center, Tifton, GA 31794; R. Torrance, Cooperative Extension Service, \\ Tattnall Co., GA 30453; R. Hartley, Cooperative Extension Service, Toombs Co., GA 30436; D. R. Sumner, De- \\ partment of Plant Pathology, University of Georgia, Tifton 31793; J. D. Gay, Cooperative Extension Service, Rural \\ Development Center, Tifton, GA 31794; and W. C. Johnson III, Nematodes, Weeds, \& Crops Unit, USDA ARS, \\ Tifton, GA 31793
}

\begin{abstract}
Gitaitis, R., MacDonald, G., Torrance, R., Hartley, R., Sumner, D. R., Gay, J. D., and Johnson, W. C., III. 1998. Bacterial streak and bulb rot of sweet onion: II. Epiphytic survival of Pseudomonas viridiflava in association with multiple weed hosts. Plant Dis. 82:935-938.

A semiselective agar medium (T-5) was used to sample environment and plant material as a habitat for Pseudomonas viridiflava. Soil, irrigation water, soybean foliage, and foliage from various weeds in an onion-growing area were assayed over a 5-year period. $P$. viridiflava was recovered only as an epiphytic resident from weed species that included cutleaf evening primrose, dandelion, common fumitory, purple cudweed, spiny sowthistle, Virginia pepperweed, and wild radish. The bacterium apparently overseasons in association with these weeds, because its presence was detected prior to, as well as during, the onion-growing season. Preliminary tests indicated that weed control may suppress bacterial streak and bulb rot levels.
\end{abstract}

Bacterial streak and bulb rot of onion (Allium cepa L.) have caused significant losses in Georgia both in the field and in postharvest storage in recent years $(5,8)$. In Georgia, sweet onions are seeded during the late summer or early fall and transplanted to production fields between the middle of November and early January. Outbreaks of bacterial streak and bulb rot occur most often and with greatest severity between January and March and during extended rainy periods. The causal bacterium, Pseudomonas viridiflava, has a worldwide distribution and an extensive host range that includes alfalfa (Medicago sativa), bean (Phaseolus vulgaris), birdsfoot trefoil (Lotus corniculatus), cabbage (Brassica oleracea var. capitata), cauliflower (B. oleracea var. botrytis), Chinese gooseberry (Actinidia chinensis), dill (Anethum graveolens), grape (Vitis vinifera), lettuce (Lactuca sativa), lupin (Lupinus angusti-

Corresponding author: R. Gitaitis

E-mail: path4@tifton.cpes.peachnet.edu

Mention of a trademark, proprietary product, or vendor does not constitute a guarantee or warranty of the product by the University of Georgia and does not imply its approval to the exclusion of other products or vendors that may also be suitable.

Accepted for publication 6 May 1998

Publication no. D-1998-0619-01R

This article is in the public domain and not copyrightable. It may be freely reprinted with customary crediting of the source. The American Phytopathological Society, 1998. folius), parsnip (Pastinaca sativa), passion fruit (Passiflora edulis), pea (Pisum sativum), pepper (Capsicum annuum), poinsettia (Euphorbia pulcherrima), poppy (Papaver somniferum), pumpkin (Cucurbita maxima), rape (B. napus var. napus), and tomato (Lycopersicon esculentum) $(2,3,10$, $12,17,19,21)$. Reported hosts by artificial inoculation include, but are not limited to, buckwheat (Fagopyrum esculentum), clover (Trifolium pratense), cowpea (Vigna unguiculata), safflower (Carthamus tinctorius), sorghum (Sorghum vulgare), soybean (Glycine max), and zinnia (Zinnia elegans) (2). The susceptibility of soybean is of particular interest, because it is the summer rotation crop used by many onion growers in Georgia.

Disease patterns in the field and the lack of reports of bacterial streak and bulb rot of onion from areas other than the southeastern United States led us to suspect a local source of inoculum. To test our hypothesis that $P$. viridiflava survives locally, we developed a semiselective medium (T-5) to use in a survey of the onion-growing area of Georgia (8). We sampled irrigation ponds, soils, soybean foliage, and weeds in areas with a history of bacterial streak and bulb rot problems. The results of these surveys are reported here.

\section{MATERIALS AND METHODS}

Survey of environment. Soil, soybeans, pond water, and weeds were collected mercurially in Montgomery, Tattnall, Tift, and Toombs counties, GA, from 1991 to 1995.
Sample sites were in areas that had a history of bacterial streak and bulb rot.

Water samples were collected from eight ponds in the onion-growing area. Water was collected from the upper $10 \mathrm{~cm}$ of the pond, using a 500-ml beaker with an extended handle $(3 \mathrm{~m})$. Samples were transferred to sterile, polypropylene bottles and placed on ice before transport to the lab. Samples $(1.0 \mathrm{ml}$ each) were serially diluted (1:9), and $0.1-\mathrm{ml}$ aliquots from the $10^{0}$ to $10^{-2}$ dilutions were spread uniformly onto medium T-5 (8) and King's Medium B (KMB) (13). Water samples also were concentrated by centrifuging $200 \mathrm{ml}$ of the sample at $3,000 \times g$ for $30 \mathrm{~min}$ and resuspending the pellet in $2.0 \mathrm{ml}$ of phosphate-buffered saline (PBS; $0.01 \mathrm{M} \mathrm{K}_{2} \mathrm{HPO}_{4}-\mathrm{KH}_{2} \mathrm{PO}_{4}, \mathrm{pH}$ 7.3 , and $0.85 \% \mathrm{NaCl}$ ). Concentrated samples were treated as described above. Plates were incubated at 5 and $25^{\circ} \mathrm{C}$. Plates were read every 5 to 7 days during a 30-day incubation period. Suspect colony forming units were removed, restreaked on KMB, and tested for their ability to produce a water-soluble fluorescent pigment. Fluorescent strains were tested further for production of oxidase, arginine dihydrolase, and pectinolytic enzymes $(1,9,11,15)$.

Soil samples were collected from 11 fields with a history of bacterial streak and bulb rot. Samples were made in specific areas of the field identified as having supported onions with the highest disease incidence and greatest disease severity during the previous season. Soil cores $(2.5 \mathrm{~cm}$ diameter, $10 \mathrm{~cm}$ deep) were collected from 16 sites on 2-line transects forming an $\mathrm{X}$ across the sample site. Soil cores were mixed thoroughly to create a composite sample for each field. Samples were placed in plastic bags, stored on ice, and transported to the lab. Soils were suspended in PBS (10 $\mathrm{g}$ of soil/100 $\mathrm{ml}$ of PBS), serially diluted (1:9) in PBS, and 0.1-ml aliquots from $10^{0}$ to $10^{-2}$ dilutions were spread on medium T-5 and KMB with a flame-sterilized, bent-glass rod. Plates were incubated and evaluated as described above.

In addition, soil samples also were taken from field plots designed to evaluate the efficacy of soil fumigants at two locations. Both sites had a history of bacterial streak and bulb rot during the previous year. The 
Toombs County site (site A) had been in a multiple cropping system of onion during the fall, winter, and spring and soybean during the summer for 5 years and had a history of onion crops for a minimum of 20 years. The Montgomery County site (site B) had a history of onion-summer fallow for 5 years. Both sites A and B consisted of plots arranged in a randomized complete block design, with four replications. Treatments of $67 \%$ methyl bromide$33 \%$ chloropicrin (126.6 or $392 \mathrm{~kg} / \mathrm{ha}$ ), chloropicrin $(123.2 \mathrm{~kg} / \mathrm{ha})$, methyl bromide concentrate $(257.6 \mathrm{~kg} / \mathrm{ha}), 1,3$-dichloropropene $(113.1 \mathrm{~kg} / \mathrm{ha}), 1,3$-dichloropropene plus $17 \%$ chloropicrin $(177 \mathrm{~kg} / \mathrm{ha})$, metam sodium $(211 \mathrm{~kg} / \mathrm{ha})$, and a nontreated control were applied as previously described (18).

Soil cores ( 80 cores, $2.5 \mathrm{~cm}$ diameter, 10 $\mathrm{cm}$ deep) were collected from sites $\mathrm{A}$ and gation) and 16 November 1991 and on 16 January and 16 March 1992 (after fumigation). Soils from each sampled area of a field were mixed thoroughly, divided into two portions per site, and $10 \mathrm{~g}$ from each portion was suspended in separate sterile beakers containing $100 \mathrm{ml}$ of PBS. Aliquots $(1.0 \mathrm{ml})$ of $P$. viridiflava suspensions were prepared as described above and added to one of the soil portions (amended) from each site to produce an estimated population of $10^{3} \mathrm{CFU} / \mathrm{ml} / \mathrm{g}$ of soil. Serial dilutions (1:9) were made in PBS, and aliquants $(0.1 \mathrm{ml})$ from each portion (amended and nonamended) were spread on the surface of test media. Colonies were counted after 3 to 5 days of incubation at $25^{\circ} \mathrm{C}$. Tests were replicated three times. Soil samples were collected and processed in a similar manner on medium T-5 at $5^{\circ} \mathrm{C}$.

Soybean leaves were collected from mature plants from six fields with a history of bacterial streak and bulb rot. Samples were collected from within fields known to contain onions with high levels of bacterial streak and bulb rot during the previous season. A total of 16 sites per field on 2-line transects that formed an $\mathrm{X}$ pattern across the entire field was sampled. Leaflets $(n=$ $\mathrm{B}$ on 20 and 21 October (prior to fumi-

32) were collected from the upper, middle, and lower one-third of the plant canopy from two plants at each site, placed in plastic bags, stored on ice, and transported to the lab. Leaflets $(1.0 \mathrm{~g} / \mathrm{ml}$, wt/vol)were bulked according to canopy position (32 per bulk sample) and shaken in PBS amended with Tween $20(50 \mu \mathrm{l} / 500 \mathrm{ml}$ of PBS $)$. Aliquots from the $10^{0}$ to $10^{-2}$ dilutions were spread on medium T-5 and KMB and incubated at 5 and $25^{\circ} \mathrm{C}$, respectively. After washing, leaflets were examined visually, and isolations were made from suspect lesions. Such isolations were made on KMB, and plates were incubated at $25^{\circ} \mathrm{C}$.

Weed samples were taken during late winter or early spring and consisted of naturally occurring common winter annual species. Weed species included cutleaf evening primrose (Oenothera laciniata Hill), dandelion (Taraxacum officinale Weber), common fumitory (Fumaria officinalis L.), purple cudweed (Gnaphalium purpureum L.), spiny sowthistle (Sonchus asper (L.) Hill), narrowleaf vetch (Vicia sativa L.), Virginia pepperweed (Lepidium virginicum L.), and wild radish (Raphanus raphanistrum L.). Samples were collected from within fields and adjacent (within $10 \mathrm{~m}$ ) to fields with a history of bacterial streak and bulb rot as well as from remote nonagricultural sites isolated from onion fields.

Weed samples were placed in plastic bags and shaken in PBS amended with Tween 20. Aliquots $(0.1 \mathrm{ml})$ from the $10^{0}$ to $10^{-2}$ dilutions were spread on medium T-5 and $\mathrm{KMB}$. Plates were incubated at 5 and $25^{\circ} \mathrm{C}$. Plates were read every 7 days during a 25to 30-day incubation period. Suspect colony forming units were picked from the isolation medium and restreaked on KMB. Once a pure culture was established, recovered bacteria were characterized for gram reaction (20), production of a water-soluble fluorescent pigment on KMB (13), ice-nucleation activity (INA) (11), pectinolytic activity at $\mathrm{pH} 8.5(7,9)$, utilization of DL-lactate $(4)$, D-tartrate (4), and sucrose (4), presence of oxidase (15), and absence of arginine dihydrolase (15). Fatty acid profiles were gen-

Table 1. Populations ( $\left.\log _{10} \mathrm{CFU}\right)$ of total bacteria, fluorescent pseudomonads, and Pseudomonas viridiflava recovered over time from soils from Toombs and Montgomery counties in southern Georgia

\begin{tabular}{|c|c|c|c|c|c|c|c|}
\hline \multirow[b]{2}{*}{ County } & \multirow[b]{2}{*}{ Population } & \multirow{2}{*}{$\begin{array}{l}\text { Isolation } \\
\text { medium }^{\text {a }}\end{array}$} & \multicolumn{5}{|c|}{$\log _{10} C F U / g$ of soil } \\
\hline & & & Oct. & Nov. & Dec. & Jan. & Mar. \\
\hline Toombs & Total bacteria & $\mathrm{T}-5$ & & 2.9 & 3.1 & 4.4 & 2.9 \\
\hline Toombs & Total bacteria & KMB & 5.9 & 4.9 & & 4.8 & 3.8 \\
\hline Toombs & Pseudomonads & T-5 & & 2.3 & 1.7 & 2.4 & 0.2 \\
\hline Toombs & Pseudomonads & KMB & 3.4 & 3.1 & & 2.0 & 3.6 \\
\hline Toombs & $P$. viridiflava & T-5 & & 0.0 & 0.0 & 0.0 & 0.0 \\
\hline Toombs & P. viridiflava & KMB & 0.0 & 0.0 & & 0.0 & 0.0 \\
\hline Montgomery & Total bacteria & $\mathrm{T}-5$ & & 0.49 & 1.5 & 1.2 & 3.7 \\
\hline Montgomery & Total bacteria & KMB & 5.6 & 3.8 & & 2.9 & 4.8 \\
\hline Montgomery & Pseudomonads & T-5 & & 0.23 & 0.25 & 0.29 & 2.5 \\
\hline Montgomery & Pseudomonads & KMB & 1.1 & 1.5 & & 1.4 & 3.5 \\
\hline Montgomery & P. viridiflava & $\mathrm{T}-5$ & & 0.0 & 0.0 & 0.0 & 0.0 \\
\hline Montgomery & $P$. viridiflava & KMB & 0.0 & 0.0 & & 0.0 & 0.0 \\
\hline
\end{tabular}

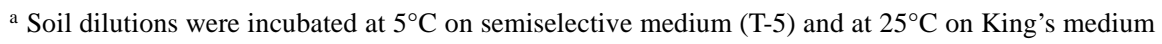
B (KMB). erated and analyzed as previously described (6). Pathogenicity was evaluated by inoculating foliage of onion plants (cv. Granex 33) grown in a greenhouse (5). Also, onion slices were cut aseptically, stab-inoculated, and incubated in petri plates at $25^{\circ} \mathrm{C}$ for 24 to $48 \mathrm{~h}$. Isolations were made from diseased tissues, and the resulting isolated bacteria were observed for key characteristics to determine identity.

\section{RESULTS AND DISCUSSION}

Survey of environment. $P$. viridiflava was not recovered from any soil, water, or soybean samples from any location in Montgomery, Tattnall, Tift, or Toombs counties, GA, from 1991 to 1995 . Incubation in semiselective medium $\mathrm{T}-5$ at $5^{\circ} \mathrm{C}$ was useful to enumerate bacterial populations with characteristics similar to $P$. viridiflava and to reduce the number of suspect colony forming units required for further analysis (8). Populations of soilborne bacteria over time are presented for two locations in Montgomery and Toombs counties (Table 1). Populations of soilborne bacteria that grew at $5^{\circ} \mathrm{C}$ and were categorized as "suspect" were $\approx 1,000$ - to 10,000 -fold fewer than total populations at $30^{\circ} \mathrm{C}$ at either site. Bacterial populations at the Toombs County site declined through the winter and either became static or continued to decline into March. However, populations at the Montgomery County site declined through the winter but increased by two orders of magnitude by March. It is unknown what caused these population trends, but the Montgomery County site had been fallow previous to the onion crop, whereas the Toombs County site had been in a continuous onion-soybean cropping system for 5 years.

Bacterial populations from these soils are of interest and may be relevant to overall plant growth and onion production because many types of bacteria, including fluorescent pseudomonads, can act as growth-promoting bacteria $(14,16)$. Also, it appeared that none of the soil fumigants reduced bacterial populations. However, in relation to the goal of this study, all of the fluorescent colony forming units recovered from either location at any time were oxidase and arginine dihydrolase positive. These key characteristics showed that these pseudomonads were not $P$. syringae or $P$. viridiflava.

Fluorescent colony forming units negative for both oxidase and arginine dihydrolase were recovered from leaf washings from cutleaf evening primrose, dandelion, fumitory, purple cudweed, spiny sowthistle, narrowleaf vetch, Virginia pepperweed, and wild radish. Weeds yielding such bacteria included fumitory, dandelion, and rabbittobacco (Gnaphalium obtusifolium L.) from areas not in cultivation in recent years and several kilometers from the nearest onion field, as well as cutleaf evening primrose from within fields of onions with a history of bacterial streak and bulb rot. Although fluorescent, oxidase negative, and arginine 
dihydrolase negative pseudomonads were recovered from all four counties surveyed and the weeds listed, they were recovered most frequently from dandelion, wild radish, Virginia pepperweed, and cutleaf evening primrose. The latter is an important weed pest within onion fields, and the first three commonly are found around field borders, within solid-set irrigation lines, or by the pivot point of center pivot systems.

Characterization of weed strains. The majority of fluorescent colony forming units commonly recovered from weed foliage that were negative for both oxidase and arginine dihydrolase and exhibited a negative gram reaction, were similar to $P$. viridiflava in that they utilized DL-lactate and D(-)tartrate but not sucrose (within 7 days), were pectinolytic at $\mathrm{pH} 8.5$, were INA positive, and were pathogenic to onion. Two strains from cutleaf evening primrose were not pectinolytic or INA positive, but all six strains from that weed were similar to $P$. viridiflava in that they did not utilize sucrose within 7 days and were pathogenic to onion. Three strains from dandelion also were not pectinolytic, but they utilized sucrose and were not pathogenic to onion. However, other tested strains from dandelion were typical of $P$. viridiflava and were pathogenic on onion. All strains from fumitory, spiny sowthistle, Virginia pepperweed, and wild radish utilized DL-lactate and $\mathrm{D}(-)$ tartrate but not sucrose, were pectinolytic and INA positive, and were pathogenic to onion, which are characteristics of $P$. viridiflava. The strain from vetch did not to utilize $\mathrm{D}(-)$ tartrate and sucrose, was not pectinolytic, was INA negative, and was not pathogenic on onion.

Similar results were obtained from fatty acid analysis. All strains were identified as either a pathovar of $P$. syringae or as $P$. viridiflava by the MIDI (Newark, DE) microbial identification system. The system typically names onion strains as a pathovar

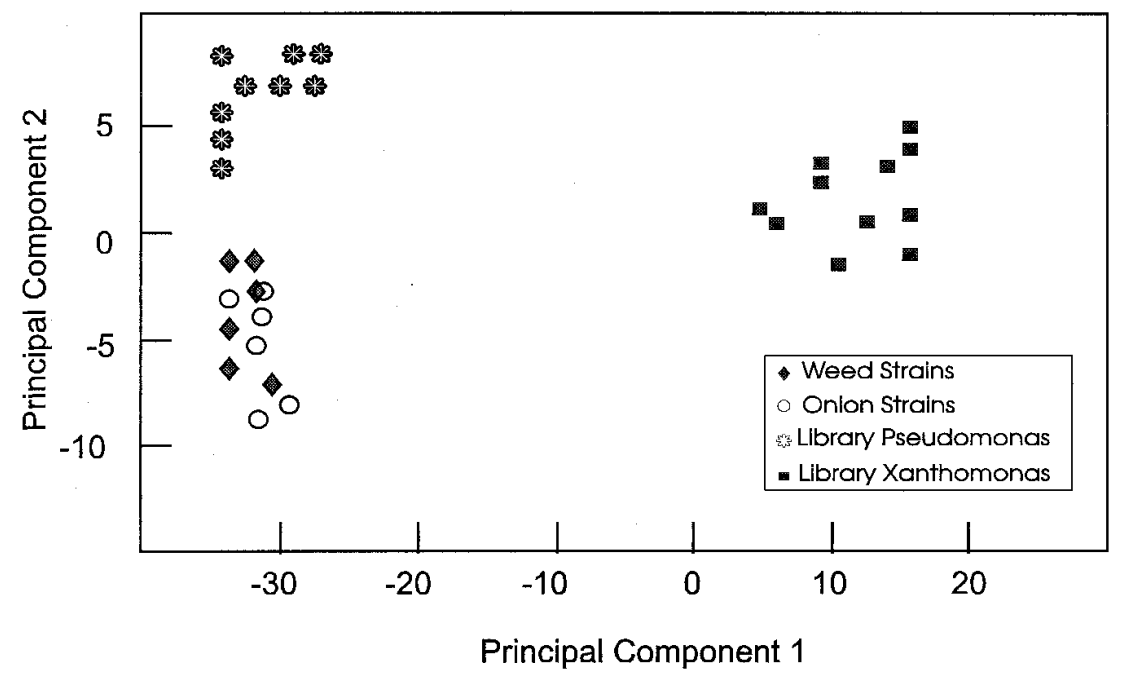

Fig. 1. Two-dimensional plot of principal components one and two derived from fatty acid analysis of bacterial strains recovered from weeds and diseased onions from Tattnall and Toombs counties, GA, compared to MIDI library strains of Pseudomonas spp. and Xanthomonas campestris pathovars. of $P$. syringae, although they routinely conform to characteristics of $P$. viridiflava. This is a further indication of how closely these two species are related. Of more interest than the naming of strains by the MIDI system was the cluster analysis and plotting of principal components of the fatty acid profiles (Fig. 1). The weed strains with characteristics the same as those of $P$. viridiflava clustered more closely to strains of $P$. viridiflava previously isolated from diseased onions in Georgia than to any other fluorescent pseudomonads, including the MIDI library strain of $P$. viridiflava, which was not from onion. This is further evidence that the weed strains are responsible for bacterial streak and bulb rot.

Summary. An intensive survey of soils, irrigation water, soybean plants, and weeds resulted in detection of $P$. viridiflava on the foliage of several species of weeds in the Vidalia onion-growing area of Georgia. We found no evidence that the bacterium survived long-term in soil or water or in association with soybean. Further evidence supporting the hypothesis that weeds serve as a source of inoculum for bacterial streak and bulb rot epidemics came from observations of one of the authors in 1994 (R. Torrance, personal communication). He observed four fields in Tattnall County that were subjected to different herbicide treatments. Oxyfluorfen is used as a postemergent herbicide and to control cutleaf evening primrose and other weeds. Fields one and two received dimethyl tetrachloroterephthalate (DCPA) on half the field and DCPA plus oxyfluorfen on the other half. Field three received DCPA on half the field and oxyfluorfen on the other half. Field four received oxyfluorfen on the entire field, except for the center three beds, which received no treatment. Approximately 200 plants per treatment were evaluated for bacterial streak and bulb rot from 12 sites within a treatment.
In field one, $11.6 \%$ of the plants were infected on the half receiving DCPA, and only $4.6 \%$ were infected on the half receiving DCPA plus oxyfluorfen. In field two, $2 \%$ of the plants were infected on the half receiving DCPA, and only $0.06 \%$ were infected on the half receiving DCPA plus oxyfluorfen. In field three, $24 \%$ of the plants were infected on the half receiving DCPA, and only $11 \%$ were infected on the half receiving oxyfluorfen. Finally, in field four, $20.3 \%$ of the plants were infected in the area of the field receiving no treatment, and only $7.6 \%$ of the plants were infected in areas receiving oxyfluorfen. There was a reduction in disease and levels of infestation on cutleaf evening primrose at all four locations in areas receiving oxyfluorfen compared to nontreated areas or areas receiving just DCPA. These data provide additional evidence that $P$. viridiflava has an integral association with weeds in the oniongrowing area of Georgia and that weed control may be beneficial in controlling this disease.

\section{ACKNOWLEDGMENTS}

We thank the Vidalia Onion Committee for their cooperation and financial support of this research.

\section{LITERATURE CITED}

1. Billing, E. 1970. Pseudomonas viridiflava (Burkholder, 1930; Clara 1934). J. Appl. Bacteriol. 33:492-500.

2. Bradbury, J. F. 1986. Pseudomonas viridiflava. Pages 183-184 in: Guide to Plant Pathogenic Bacteria. $\mathrm{CAB}$ International Mycological Institute, England.

3. Burkholder, W. H. 1930. The bacterial diseases of bean: A comparative study. Mem. 127 N.Y. Agric. Exp. Stn. Ithaca.

4. Gerhardt, P., Murray, R. G. E., Costilow, R. N. Nester, E. W., Wood, W. A., Krieg, N. R., and Phillips, G. B., eds. 1981. Manual of Methods for General Bacteriology. American Society for Microbiology, Washington, DC.

5. Gitaitis, R. D., Baird, R. E., Beaver, R. W., Sumner, D. R., Gay, J. D., and Smittle, D. A 1991. Bacterial blight of sweet onion caused by Pseudomonas viridiflava in Vidalia, Georgia. Plant Dis. 75:1180-1182.

6. Gitaitis, R. D., and Beaver, R. W. 1990. Characterization of fatty acid methyl ester content of Clavibacter michiganensis subsp. michiganensis. Phytopathology 80:318-321.

7. Gitaitis, R. D., Sasser, M. J., Beaver, R. W. McInnes, T. B., and Stall, R. E. 1987. Pectolytic xanthomonads in mixed infections with Pseudomonas syringae pv. syringae, $P$ syringae pv. tomato, and Xanthomonas campestris pv. vesicatoria in tomato and pepper transplants. Phytopathology 77:611615.

8. Gitaitis, R., Sumner, D., Gay, D., Smittle, D., MacDonald, G., Maw, B., Johnson, W. C., III, Tollner, B., and Hung, Y. 1997. Bacterial streak and bulb rot of onion: I. A diagnostic medium for the semiselective isolation and enumeration of Pseudomonas viridiflava. Plant Dis. 81:897-900.

9. Hildebrand, D. C. 1971. Pectate and pectin gels for differentiation of Pseudomonas sp. and other bacterial plant pathogens. Phytopathology 61:1430-1436.

10. Hunter, J. E., and Cigna, J. A. 1981. Bacterial blight incited in parsnip by Pseudomonas marginalis and Pseudomonas viridiflava. Phyto- 
pathology 71:1238-1241.

11. Jones, J. B., Gitaitis, R. D., and McCarter, S. M. 1986. Fluorescence on single-carbon sources for separation of Pseudomonas syringae pv. syringae, $P$. syringae pv. tomato and $P$. viridiflava on tomato transplants. Plant Dis. 70: 151-153.

12. Jones, J. B., Jones, J. P., McCarter, S. M., and Stall, R. E. 1984. Pseudomonas viridiflava: Causal agent of bacterial leaf blight of tomato. Plant Dis. 68:341-342.

13. King, E. O., Ward, M. K., and Raney, D. E. 1954. Two simple media for the demonstration of pyocyanin and fluorescein. J. Lab. Clin. Med. 44:301-307.

14. Kloepper, J. W., Lifshitz, R., and Schroth, M. N.
1988. Pseudomonas inoculants to benefit plant production. Anim. Plant Sci. 1:60-64.

15. Lelliott, R. A., Billing, E., and Hayward, A. C. 1966. A determinative scheme for the fluorescent plant pathogenic pseudomonads. J. Appl. Bacteriol. 29:470-489.

16. Lifshitz, R., Kloepper, J. W., Kozlowski, M., Simonson, C., Carlson, J., Tipping, E. M., and Zaleska, I. 1987. Growth promotion of canola (rapeseed) seedlings by a strain of Pseudomonas putida under gnotobiotic conditions. Can. J. Microbiol. 33:390-395.

17. Lukezic, F. L., Leath, K. T., and Levine, R. G. 1983. Pseudomonas viridiflava associated with root and crown rot of alfalfa and wilt of birdsfoot trefoil. Plant Dis. 67:808-811.
18. Sumner, D. R., Gitaitis, R. D., Gay, J. D., Smittle, D. A., Maw, B. R., Tollner, E. W., and Hung, Y. C. 1997. Control of soilborne pathogenic fungi in fields of sweet onion. Plant Dis. 81: 885-891.

19. Suslow, T. V., and McCain, A. H. 1981. Greasy canker of poinsettia caused by Pseudomonas viridiflava. Plant Dis. 65:513-514.

20. Suslow, T. V., Schroth, M. N., and Isaka, M. 1982. Application of a rapid method for gram differentiation of plant pathogenic and saprophytic bacteria without staining. Phytopathology 72:917-918.

21. Wilkie, J. P., and Dye, D. R. W. 1973. Further hosts of Pseudomonas viridiflava. N.Z. J. Agric. Res. 16:315-323. 